\title{
Jacques Derrida og den hæretiske hermeneutik *
}

Jøden er en ekspert i den uopfyldte tid.

Arthur Cohen

\begin{abstract}
I Algier, midt i en moske, som kolonisterne havde lavet om til en synagoge, bliver Toraen, når den tages frem fra sin plads bag forhænget [derrière les rideaux], båret rundt i armene på en mand eller et barn... Børn, der har oplevet det pragtfulde ved denne højtidelighed, specielt de, der var i stand til at give en hånd med, drømmer måske om det længe efter, drømmer om dér at arrangere alle stumperne af deres liv.

Hvad er det jeg gør her? Lad os sige, at jeg bearbejder litteraturens oprindelse ved at mime den. Mellem de to (1).
\end{abstract}

Den, der taler, er Derrida i en selvbiografisk passage i Glas. Og vi må også spørge, hvad er det Derrida gør her - afslører den tilslørede papirrulle, den tilslørede skrift, og her arrangerer alle stumperne af sit liv? Gayatri Spivak fortolker denne passage som det jødiske barns inspiration ved fraværet af faderen, eller sandheden bag forhænget, en inspiration, der tillader ham at anbringe sin selvbiografi på den plads, der producerer litteraturens "oprindelse" (2).

At anbringe sin selvbiografi i Toraens sted er, først og fremmest, at forskyde den vigtigste og mest autoritative jødiske tekst - og alligevel samtidig paradoksalt at fortsætte den, "dér at arrangere alle stumperne af sit liv." Og dette gør Derrida med sin altfavnende teori om écriture. Écriture oversættes sædvanligvis som "skrift" [writing], men kan også oversættes som "den hellige skrift" [scripture]. De fleste Derrida-læsere forstår hans forskydninger, hans fordrejninger og hans mimen som en ekstrem udvidelse af en nietzscheansk-heideggersk "dekonstruktions"-tradition. Jeg vil ikke desto mindre fastholde, at de i lige så høj grad må forstås som en ekstrem udvidelse af en lang tradition for en rabbinsk "hæretisk hermeneutik" i forhold til den hellige skrift, der rummer så forskellige figu-

(*) Oversat fra "Jacques Derrida and the Heretic Hermeneutic" i Displacement: Derrida and After (red. af Mark Krupnick), Indiana Univ. Press, Bloomington 1983, s. 98-129. 
rer som apostlen Paulus, Freud og Harold Bloom. Og denñe hæretiske hermeneutik udspringer selv af indre forskydninger af den rabbinske tænkning.

"Forskydning" kan faktisk siges at være et nøglebegreb for jødisk hermeneutik i almindelighed og udgør selvsagt det jødiske eksils historiske betingelse. I sit essay om den fransk-jødiske forfatter Edmond Jabès sporer Derrida denne forbindelse mellem jøden-som-eksil og skriften:

...det drejer sig om en særlig jødedom som skriftens fødsel og lidenskab. Skriftens lidenskab, kærligheden og vedholdenheden ved selve bogstavet, hvis genstand ikke afgørligvis er jøden eller bogstavet selv...

Udvekslingen mellem jøden og skriften som en ren og fundamental udveksling, en udveksling uden prærogativer indeholdende den oprindelige appel, i en anden betydning af ordet en konvokation... Og gennem en art stum forskydning henimod det essentielle... bliver jødens situation eksemplarisk for digterens situation, mennesket af tale og skrift...

Digteren og jøden er ikke født her men et andet sted. De strejfer om adskilt fra deres sande oprindelse. Autoktone kun i tale og skrift, i loven. "Børn af bogen" fordi de er sønner af det land, der skal komme...

Kommentarens nødvendighed er, ligesom den digteriske nødvendighed, selve den eksilerede tales form. I begyndelsen er hermeneutikken (3).

Digteren og jøden er ikke rodfæstet i nogen empirisk naturlig nutid; de er aldrig her, men altid der, fortsætter Derrida; de strejfer om i ørkenen, hvor den ældgamle fortid også er fremtiden. De er kun indfødte i ordet og i den hellige skrift; jødernes hjem er en hellig skrift midt iblandt kommentarer. Jøden, siger Derrida, valgte den hellige skrift (skriften-écriture), som valgte jøden. Også digteren er "valgt", udvalgt af ordene, og er antaget til det arbejde at levere det digt, som han er fader til. Også digteren er bogens subjekt, dens indhold og dens herre, dens tjener og dens tema; og bogen er digterens subjekt (4).

At være både bogens herre og tjener er i sig selv et paradoksalt vilkår; det definerer den kreative spænding i det rabbinske forhold til teksten. For jøderne som "bogens folk" er det centrale spørgsmål, hvordan man kan omgås en kanonisk, guddommelig tekst, som gør krav på at være selve essensen af virkeligheden. Med andre ord, det centrale problem drejer sig om fortolkning. (Med Harold Blooms udtryk, hvordan behandler den forsinkede kommentator-kritikerdigter den overvældende indflydelse fra en tidligere, autoritativ, faderlig tekst? (5)). Som en løsning skabte rabbinerne et system af fortolkning, der selv blev en anden lige så autoritativ kanon, en anden hellig skrift. De kaldte den "den mundtlige Tora" (skønt den nu har været nedskrevet i omkring 2000 år), og den er deres egen ledsagende fortolkning, forstærkning og diskussion af meningen med den skrevne Tora - det Gamle Testamentes hellige skrifter. (Med "rabbine- 
re" refererer jeg her til den gruppe af vismænd, skriftkloge og fortolkere fra Ezra efter tilbagekomsten fra Babylon i det femte århundrede før Kristus til fuldendelsen af den Babyloniske Talmud, "den mundtlige Tora" - omkring det femte århundrede efter Kristus).

\section{Israels to huse}

Med Simon Rawidowicz' ord skabte rabbinerne i denne periode i virkeligheden en "anden begyndelse", et Israels "andet hus" i kontrast til de oprindelige hellige skrifters "første begyndelse" og "første hus" (6). Deres mageløse og dristige bedrift var at fremstille dette andet hus, denne mundtlige Tora (deres kommentar og fortolkning), som ikke bare har en autoritet på linje med de originale hellige skrifter fra det første hus, men på visse måder endda er mere autoritativ end disse (en art forskydning igen).

Der er en berømt talmudisk passage, som giver en god beskrivelse af denne holdning. R. Eliezer diskuterede med vismændene hvorvidt en bestemt ovn var ren eller uren i rituel henseende:

Den dag fremførte R. Eliezer ethvert tænkeligt argument, men de [andre rabbinere] accepterede dem ikke. Han sagde til dem: "Hvis loven er på min side, så lad dette karob-træ bevise det!" Derpå flyttede karob-træet sig hundrede tommer - andre bevidner, at det flyttede sig fire hundrede tommer. "Et karob-træ kan ikke bevise noget," svarede de skarpt. Så sagde han til dem: "Hvis loven er på min side, så lad vandløbet bevise det!" Hvorpå vandløbet løb baglæns. "Et vandløb kan ikke bevise noget," svarede de igen... Så sagde han til dem: "Hvis loven er på min side, så lad Himlen bevise det!" Hvorpå en himmelsk stemme råbte: "Hvorfor diskuterer I med R. Eliezer, når I kan se, at i alle spørgsmål er loven på hans side!" Men R. Joshua rejste sig og udbrød: "Det er ikke i Himlen!" Hvad mente han hermed? R. Jeremiah sagde: At Toraen allerede er blevet givet os på Sinaj-bjerget; Vi tager os ikke af en himmelsk stemme, fordi Du allerede for længst har skrevet i Toraen på Sinaj-bjerget, "Man må bøje sig for flertallet".

R. Nathan mødte Elias og spurgte ham: "Hvad gjorde da Den Hellige, velsignet være Han? - Han lo, svaredehan, og sagde: "Mine sønner har besejret mig, mine sønner har besejret mig". [Bava Metzia 59 a \& b]

Denne historie illustrerer fromt og billedligt den indre dynamik i den rabbinske tænkning: den indeholder i sig muligheden for sine egne fortolkningsmæssige omstødelser (trods enhver guddommelig stemme om det modsatte - faktisk blev stakkels R. Eliezer ekskommunikeret efter denne hændelse, trods opbakning fra Himlen). Disse fortolkninger fuldføres frem for alt gennem reviderende fortolkninger (forskydninger), som tager form af og forstår sig selv som en ny from 
kommentar til teksten. For eksempel angiver teksten til femte Mosebog 21:1821 udtrykkeligt, at en oprørsk søn skal stenes til døde. Rabbinerne hævdede imidlertid, at loven kun trådte i kraft, hvis sønnen begik overtrædelsen i løbet af tre måneder af sit 13. år, og kun hvis rettergangen er fuldført på samme tid, og gjorde det således praktisk umuligt at anvende loven. Om dette vers skriver de: "Der har aldrig eksisteret en stædig og oprørsk søn, og der vil aldrig komme til det. Hvorfor blev loven da skrevet? For at man kan studere den og få udbytte" (Sanhedrin 71a).

Der sker imidlertid en spidsfindig omvending af tekst og kommentar her indtil rabbinerne sluttelig erklærede: "Alt det, en begavet student i fremtiden vil udlægge foran sin lærer, blev allerede givet til Moses på Sinaj" (Yer. Peah 6:2). Det vil sige, at al senere rabbinsk fortolkning har del i den samme guddommelige oprindelse som Moses' Tora; med Derridas ord var fortolkningen der "altid allerede". Den menneskelige fortolkning og kommentar bliver således en del af den guddommelige åbenbaring! Grænserne mellem tekst og kommentar er flydende på en måde, som er vanskelig at forestille sig i forhold til en hellig tekst; men denne flyden er en grundsætning for nutidens kritik-teori, og specielt hos Derrida. Geoffrey Hartman fremlægger for eksempel det synspunkt, at enhver absolut distinktion mellem litterær kritik (kommentar) og litteratur (tekst) er naiv, at "Der findes ikke nogen absolut viden, men snarere noget tekstuelt uendeligt, et grænseløst væv af tekster eller fortolkninger" (7).

Eksegesens grænse vil derfor tendentielt være lige så usikkert udvidelig som tekstens. Eksegesens hovedanliggende er faktisk denne "grænse". Dog krydser kritikken som kommentar de lineam altid grænsen og ændrer sig til en kommentar trans lineam. Kommentatorens diskurs kan således ikke adskilles rent eller metodisk fra forfatterens: forholdet er smittende og kiastisk, den oprindelige tekst og den sekundære tekst indgår, skønt de kan skilles ad, i et gensidigt støttende og gensidigt dominerende forhold (8).

Spørgsmålet om smitte og overskridelse er vigtigt. Hvornår bliver den smittende kommentar til en fordrejning og forskydning? Og, idet vi vender tilbage til vores tema om den rabbinske hæretiske hermeneutik, hvornår bliver den radikale revisionisme i den rabbinske tænkning antitetisk? Ført ud i ekstremen, eller under pres fra en historisk eller personlig katastrofe og behovet for at finde mening i den hellige skrift i overensstemmelse med en modsætningsfyldt samtidig erfaring, kan kommentar og fortolkning kamme over i kætteri - under dække af en udvidelse af det kanoniske eller endda i form af et åbent oprør. Kristendommen for eksempel nedbryder den rabbinske lov, idet den hele tiden hævder at være den sande udvidelse og korrekte fortolkning af det nu "Gamle" Testamen- 
te. Inden for jødedommen påstod ligeledes Shabbati Zevi's falske messianske proklamationer i det syttende århundrede at være en ny fuldendt fortolkning af Toraen; og der er talrige andre eksempler på splittelser, uenigheder og omstillinger - nogle er forblevet inden for jødedommen, andre har helt brudt med den.

Den vigtige pointe er, at den faktor, som forklarer essensen, vitaliteten og kreativiteten i den rabbinske jødedom (og måske er hemmeligheden bag den jødiske overlevelse i eksilet), er den samme, som kan føre til dens nedbrydning: det er den "forskudte forskydning". Enhver jødisk hæretisk hermeneutik har nedbrudt Toraen ved hjælp af Toraen - hvad enten det er Paulus' eller Derridas fortolkninger. Rabbinsk forskydning har altså været brugt til at omstyrte og forskyde rabbinerne. Sagt i korthed er den hæretiske hermeneutik et kompleks af identifikation og forskydning; den er uløseligt knyttet til en jødisk tradition for hellig skrift og eksegese, som den vender op og ned på, men som dog beholder en tvingende magt.

Selv i deres "kanoniske" hermeneutik udfører rabbinerne, med Rawidowicz' ord, "en revolution indefra", idet de frit omformer og omskaber de hellige skrifter, som er givet dem. Deres fortolkningsmåde, siger han, udgør en model for fortolkning i almindelighed, fordi deres kampe, som alle fortolkeres, blev affødt af spændingen mellem kontinuitet og oprør, hengivenhed for teksten og fremmedgørelse fra den. De lærer mennesket "samtidigt at løsrive sig og stabilisere sig, i samme åndedrag at forkaste og bevare, at bryde og bygge - indvendigt, indefra, at kaste et nyt lag oven på et tidligere lag og sammensvejse dem til en form (hvilket senere blev den jødiske tænknings og værens store problem)" (9).

Det centrale spørgsmål er imidlertid her, hvordan rummer man revolutionen i det "indvendige"? Hvad er grænsen mellem indenfor og udenfor, og hvad sker der, når kommentaren krydser denne grænse? Dette blev virkelig det store problem for jødisk tænkning og væren - specielt for post-oplysningens jøder, der som Freud, som Bloom, som Derrida har assimileret sig til det udvendige, til den vestlige sækulariserede kultur, og som har indoptaget den vestlige filosofi, men stadig drømmer om ceremonien omkring Toraen, om dér at arrangere alle stumperne af deres liv, og som drømmer om en altomfattende hellig skrift, der sammenvæver virkelighedens fragmenter og samtidig udsår nye meninger gennem sine fortolkende sønner.

Af denne grund er Derrida, som tilhørende denne hæretiske hermeneutik, besat (ligesom Freud og Bloom) af spørgsmålet om oprindelser og af behovet for at nedbryde, gen-skrive eller usurpere oprindelsen - frem for alt gennem reviderende fortolkninger. Dette er selvfølgelig også en forskydning af "faderen" - det autoritative grundlæggende princip. Derridas skydeskive er alle filosofiens fædre. Hans projekt: at dekonstruere hele den vestlige "onto-teologiske" tradition, at nedbryde "logocentrismen", at sende ordet i skriftens eksil 


\section{Hellig skrift versus logos}

Det er i første del af Om grammatologi, at Derrida klarest gør rede for sin teori om skrift. I hans $\varnothing j n e$ har hele metafysikkens historie fra prasokratikerne til Heidegger overdraget sandheden til logos og "nedvurderet" og "undertrykt" skriften. Det talte ord er blevet anset for at være tættere på den "indre" sandheds umiddelbarhed, og det skrevne ord synes blot at være en anden-hånds, en ydre og uvæsentlig fordobling, en "værdiløs sekundaritet". Derrida vil bryde sammenhængen mellem sandhed og logos og nedbryde den videnskab om betydningen, som privilegerer den foniske signifiant, og vil dermed frelse skriften fra dens nedvurderede status. Frem for alt er skriften et område, ikke for nærværet hvortil stemmen er så intimt knyttet - men for fravær, udsættelse og forskel, som alle bliver værdibegreber for Derrida. På den anden side smelter fonocentrisme og logocentrisme sammen med bestemmelsen af væren som nærvær, hvad enten det er tingens eller synets nærvær, eller nærvær som substans, essens, eksistens - eller cogito'ets, bevidsthedens eller subjektivitetens selv-nærvær og så videre.

Talens umiddelbarhed, det nære slægtskab mellem stemme og væren, støtter privilegeringen af fone som en ikke-ekstern, ikke-kontingent, ikke-empirisk signifiant. Der opstår dermed en hel serie af oppositioner: forskellen mellem jordisk/ikke-jordisk, ydre/indre, idealitet/ikke-idealitet, universelt/partikulært, transcendentalt/empirisk.

Herudover markerer Derrida overalt det "onto-teologiske" grundlag (og tilbøjelighed) i den vestlige tænkning, den teologiske tænknings effekt på vores begreber om mening, fortolkning og sandhed. Den handling at skelne mellem signifiant og signifié og postulere deres ydre forhold til hinanden tilhører "den epoke, hvor den kristne skabelses- og uendelighedstænkning tilegner sig den græske begrebsligheds resourser" (10). Derrida er optaget af at afsløre tegnteoriens "metafysisk-teologiske rødder", en teori, der i hans øjne er fuldstændig afhængig af distinktionen mellem det sansemæssige og det intelligible. Denne distinktion fører til differentieringen af signifiant og signifié og postulerer en signifié, der er rent intelligibel - en absolut, ideel logos eller den uendelige, skabende subjektivitet i den middelalderlige teologi: "Tegnet og det guddommelige befinder sig samme sted og opstår sammen. Tegnets epoke er væsentlig teologisk" (11). I denne epoke bliver signifianten tugtet som en indirekte udvendighed, hvilket bliver til skriftens udvendighed i almindelighed. Signifiéen er altid direkte relateret til logos og kun indirekte til signifianten, det vil sige skriften.

Det, Derrida siger, er uden tvivl sandt i den kristne tradition. Imidlertid kan den rabbinske tænkning karakteriseres præcis ved dens undvigelse fra denne græsk-kristne onto-teologiske tænkemåde. For rabbinerne går skriften, teksten 
ikke blot forud for talen, den går forud for hele den naturlige verden. Rabbinsk tænkning bevæger sig ikke fra det sanselige til den ideale, transcendentale signifié, men fra det sanselige til teksten.

For eksempel skelnes der ofte mellem det hebræiske davhar og det græske logos, som siden blev logos'et i den berømte åbning af Johannesevangeliet: "I begyndelsen var logos" (12). Davhar betyder både "ord" og "ting", men ting, ikke i betydningen res, substans, men i betydningen "essentiel virkelighed". For hebræeren er sproget ikke et udvendigt område (som det er for grækeren), et ufuldkomment, imitativt område, men konstituerer essensen af virkeligheden. Den hellige skrift er langt vigtigere end naturen. Den græske ontologi, som Derrida angriber, adskiller på den anden side sprog fra væren og styrer sandhedss $\varnothing$ geren hen imod en tavs ontologi.

Platon forviste selvfølgelig digterne fra sin republik og taler nedsættende om skriften, særlig i Phaidros. Den fremskriden, han forlanger, går fra ordet til tingen til formen. Viden om væren fås fra væren selv, ikke fra sproget. Også det kristne ord er et ord, som "fuldbringer" og transcenderer sproget gennem den centrale doktrin om inkarnationen. Ordet bliver $k \varnothing d$ og bringer den rabbinske fortolknings lange kamp til ende og erstatter det nu "Gamle" Testamente med det "Nye", fuldbragte. Men for rabbinerne er interpretation, ikke inkarnation, den centrale hellige handling.

Rabbinsk tænkning har altid været en "alternativ metafysik". Dette skyldtes delvis den bibelske doktrin, at verden var skabt, og ikke som i den græske anskuelse, evigt eksisterende. Og dette syn indeholdt, som Hans Jonas peger p̊̊, en indre "antimetafysisk kraft", der "førte til nedbrydningen af den klassiske metafysik og i sit resultat ændrede hele filosofiens karakter... Den bibelske doktrin satte kontingens ind imod nødvendighed, partikularitet imod universalitet, vilje imod intellekt. Den sikrede en plads for det kontingente inden for filosofien og imod filosofiens oprindelige tilbøjelighed" (13). I den bibelske anskuelse var alting kontingent, fordi der ikke var nogen $n \phi d v e n d i g$ eksistens.

Ligeledes kunne rabbinsk logik ikke grundes på nødvendige aksiomer iboende tingenes natur, som leverede pæne syllogismer og universelt sande udsagn. I stedet var den dialektisk, betinget, varsom med almene udsagn, opmærksom på de fordringer, som det partikulære stiller, og ufravigelig skeptisk - også over for fornuften.

Idet den var baseret på det centrale værens-princip, koncentrerede den græske logik sig om relationen mellem subjekt og prædikat, forbundet ved kopulaet $\mathrm{er}$. Rabbinsk logik var i modsætning hertil fokuseret på sidestillings-, nærheds- og associationsrelationer. Hebræisk har ikke nogen form af verbet "at være" i nutid. Prædikative udsagn konstrueres sprogligt gennem en sidestilling af nominale former i fri orden - og denne sproglige struktur kan ligge til grund for det 
rabbinske logiske princip om prædikation gennem sidestilling (14).

Yderligere hævdede rabbinerne, at selve verden var skabt gennem teksten: "Gud så i Toraen og skabte verden" (Bereishit Rabbah 1:1). Den hebræiske davhar var et aspekt af den hellige skabende kraft. Kristendommen tog dette ikkeontologiske begreb om en præeksisterende Tora, gennem hvilken verden var skabt, og kombinerede det med de græske begreber for substans og væren, og udviklede den inkarnerede logos. Logos betød oprindeligt "at samle, arrangere, ordne", og havde intet at gøre med talefunktionen; det betød snarere et rationelt ordnende princip. I kristendommen blev dette ikke-sproglige ordnende princip til en teofani, en synlig fremtrædelse i inkarnationen.

Og heri ligger selvfølgelig også standard-kontrasten mellem den græske understregning af synet og den hebræiske understregning af hørelsen. At se er nærvær, fylde; at høre implicerer fravær. Når synet er den fremherskende form, så vil ligheden - i jagten på videns identitet - blive defineret som kopi, repræsentation, og tænkningen bliver specu-lativ, spejlende. Og det er præcis dette syn på viden og mimesis, som Derrida og den dekonstruktive kritik angriber.

\section{Bogstavet og ånden}

Den græske forståelse af sproget som et tegn, der repræsenterer ved at abstrahere fra det partikulære og pege mod det usynlige, er en del af hele den større bevægelse fra det sanselige til det ikke-sanselige, der ifølge Derrida er en af filosofiens kardinalsynder. I forlængelse af Heidegger hævder Derrida, at det metafysiske kun eksisterer på det metaforiske område (15) - dette tvetydige, ikkesyllogistiske område af sproget, hvor et begreb samtidig både "er" og "ikke-er". Paul Ricœur bemærker en slags logisk kætteri ved metaforen og kalder det "afvigende attribution", "kategoriel transgression", "semantisk impertinens" (16).

Fra et aristotelisk synspunkt (Retorik 1457b) opfattedes metaforens billedlige betydning som en slags overføring og afvigelse i forhold til den "egentlige" betydning, som den var en erstatning af. Den endelige bestemmelsesgrund for, hvad der var "egentlig", var alle tings sande prædikat, den græske metafysiks grundlæggende princip, den centrale ousia, den utvetydige væren hinsides sproget, der ikke desto mindre tillader hele systemet af ord og ting at operere. Rekonstruktionen af den egentlige betydning resulterer i "ophævelsen" af den billedlige betydning, som blot er en udsmykning, en fremmed afvigelse, som ved hjælp af en vis lighed med den egentlige betydning fungerer som en erstatning for den.

Den metaforiske overføring fra den "egentlige" til den "billedlige" betydning er ifølge Heidegger og Derrida baseret på en metafysisk overførsel fra det "sanselige" til det "ikke-sanselige" område, en overføring, der er så afgørende for 
den vestlige tænkning. Hele den vestlige tænknings ontologiske tradition er baseret på den platoniske overføring af sjælen fra den synlige til den usynlige verden. Sanselig versus ikke-sanselig bliver altså bogstavelig versus billedlig, og derefter, i den kristne tænkning, bogstavet versus ånden.

En af de centrale debatter mellem jødedom og kristendom angik spørgsmålet om bogstavet versus ånden. Kristendommen revsede jødedommen som det døde bogstavs religion, som en pervers og blind hengivelse, der fornægter det lys, som gennem Jesus kastes over den "åndelige mening". Paulus formulerer det mest direkte: "Thi bogstaven slår ihjel, men Ånden gør levende" (2. Kor. 3:6). I sine mere generøse $\varnothing$ jeblikke fortolker Paulus bogstavet, loven eller den skrevne kodeks som en midlertidig "afbildning" eller "afskrift" af den fuldbyrdelse, der skal komme med Jesus. Den åndelige fortolkning genindfører således den "egentlige" betydning i teksten og gør alt det foregående (det Gamle Testamente) til blot en skygge i forhold til det indhold (bogstaveligt), som Jesus repræsenterer. Jesus bliver det sande prædikat for alle udsagn, den eneste og endelige referent, en referent helt hinsides sproget, hvis fremkomst annullerer den jødiske hellige skrift, som nu betragtes som en lang afvigelse, omvej, et eksil. Den mundtlige Tora er fuldstændig ugyldiggjort.

Paulus og kirkefædrene efter ham udskiftede den forlængede rabbinske meditation over og af teksten med Jesus' rene og uformidlede nærvær, som løser alle modsætninger, stabiliserer betydningen, tilvejebringer endelig identitet og lader forskellene falde sammen. Sprog, argumenter og spil af differenser hindrer den direkte forenings umiddelbarhed. Med rekonstruktionen af substansen forsvinder skyggerne, og det, der er tilbage, er den direkte forening med Jesus' nærvær. Paulus er ikke bare antinomistisk, han er også antitekstlig. Han er utålmodig og frustreret over jøderne, fordi de klamrer sig til "bogstavet"; det vil sige, at de ikke vil læse teksten kristocentrisk: "Men deres sind bliver forhærdet; ... lige til denne dag ligger der et dække over deres hjerte, når Moses oplæses; men hver gang en omvender sig til Herren, tages dækket bort" (2. Kor. 3:14-17).

Jøden vil altså ikke opgive den hellige skrift til fordel for logos. Jøden nærmer sig det guddommelige gennem en endnu mere intens koncentration om teksten ikke gennem en transcendent vision af ånden, som gør en ende på fortolkningsarbejdet. Teksten er for rabbinerne en kontinuert frembringer af betydning, som udspringer af den indre logik i det guddommelige sprog - af bogstavet selv. Betydningen tænkes ikke i en ikke-sproglig sfære, ekstern i forhold til teksten. Sproget og teksten er, for at bruge Derridas terminologi, stedet for og spillet af forskelle; og sandheden, som den blev forstået af rabbinerne, var ikke en $\emptyset j e-$ blikkelig afsløring af den Ene, men en fortsat fortolkningsproces, som Gud selv deltager $\mathrm{i}$, idet han lærer, hvad rabbinerne har at sige.

Jøderne forstod ordet-der-blev-kød doktrinen som en hedensk bogstaveligg $\varnothing-$ 
relse og en blindhed, Og hedenskab har netop at gøre med ontologi. De kristne ontologiserer davhar, de "bogstaveliggør metaforen". De opløser forskellen mellem Gud og menneske, mellem hellig skrift og natur. Derrida ser på samme måde den vestlige filosofis og videnskabs synd som en bogstaveliggørelse af metaforen og en metaforisering af bogstavet. Eller snarere, i og med at han nedbryder ousia, væren, græsk ontologis primære prædikat og essens, nedbryder han også den metafysiske opposition mellem egentlig og billedlig mening. For både Derrida og rabbinerne er afgudsdyrkelse altså tingsligg $\emptyset$ relsen af tegnene, billedmageri, tilføjelsen af ontologi til tekstualiteten.

Augustin for eksempel, en eksemplarisk kristen teolog, beskylder jøderne for en hårdnakket klæben ved tegnene - i stedet for de ting, de må formodes at betegne, og en afvisning af troen på Jesus, "fordi han ikke behandlede tegnene $\mathrm{i}$ overensstemmelse med den jødiske opfattelse" (De doctrina christiana III:6). Den kristne frihed, siger han, er frihed fra tegnene, idet de "ophøjes til de ting, de betegnede. Tegn kan således blive til sakramenter, påkaldelser af nærværet af det, som de peger på; de "fuldbyrdes" således i nærværet af "tingen", som annullerer det nu "tomme ord". Jesus er lovens endeligt.

Men denne annullering af tegnet til fordel for tingen er for jøden præcis afgudsdyrkelse. John Freccero udfolder Yehezkel Kaufmanns indsigter:

Det jødiske begreb om afgudsdyrkelse var en form for fetichisme, tilbedelsen af tingsliggjorte tegn blottet for betydning. Ikke-jødernes guder havde samme udstrækning som deres repræsentationer, som om de ikke opholdt sig på Olympen eller i himlen, men inden i en guldkalv eller en sten eller et stykke træ. Tegn peger på et fravær eller på en betydning, der først skal komme. Afgudsbilleder, som jøderne forstod dem, var ligesom feticher desperate forsøg på at gengive narvarr, et tingsliggjort tegn, man kunne næsten sige en metafor. Som jøderne så det, er det næsten som om ikke-jøderne søgte at undslippe den temporalitet, der er knyttet til de menneskelige vilkår, ved at tingsliggøre tegnene og derved eviggøre betydningen i det her- og nuværende (17).

Derridaismen er ligeledes en hårdnakket fastholden ved tegnenes fri-spil, en afvisning af at stabilisere det eller indsætte utvetydige referenter, som fuldender det. Ud fra et augustinsk eller paulinsk synspunkt er sådan en sproglig mangfoldighed imidlertid en konsekvens af syndefaldet. Tabet af en stabil referent som grundlag for ordenes bogstavelige og "egentlige" betydning er en form for eksil. Sproget er en omvej, en beklagelig formidling, en forstyrrelse mellem menneske og Gud (18). Flydende signifianter, fortolkningens spil, er afvigelser fra de "virkelige" referenter. Derridas spil af forskel, rabbinernes uendelige fortolkning og kommentar, er for den kristne et uacceptabelt eksil - en forskydning fra 
den sande væren. Og med kirkefaderen Kyrillos af Aleksandria's ord:

Jøderne er de mest forstyrrede af alle mennesker. De har ført ugudeligheden ud i dens yderste konsekvens, og deres vanvid overgår endda grækernes. De læser de hellige skrifter og forstår ikke hvad de læser. Selv om de havde det himmelske lys fra oven, foretrækker de at vandre i mørke. De er som folk, der hverken har deres sjæl eller deres tænkeevne. Følgelig er de grebet af mørket og lever som i natten (19).

Dette var virkelig en kontrovers mellem læsemåder, så det forslog. De kristne spekulerede over hvilken hemmelig overenskomst, jøderne kunne have med Satan for at leve så udmærket inden for forskellens område, $i$ tegnenes uendelige regres, $\mathrm{i}$ ordenes og fortolkningernes kakofoni, i bogstavets endeløse referentialitet, uden det frelsende endelige nærvær af ordet.

\section{At sprænge den hellige familie}

Fortolkning, formidling, forskydning, udsættelse, eksil, fravær, tvetydig betydning - dette er temaerne for rabbinsk og derridask fortolkning. For jøderne, som for Derrida, har der ikke været nogen frelse, der findes intet opfyldt nærvær. Og ikke-opfyldelsen er, som Jean-François Lyotard påpeger, karakteristisk jødisk. Jødedommen er ikke, skriver han, en religion om forsoningen mellem fader og søn, hvor den Anden (fader) vender tilbage til det samme. I jødedommen er der mellem fader og søn det, Lyotard kalder en "alliance, en præforsoning", fordi sønnen er besat af faderens stemme gennem tekstens gave. Kristendommen er "ødipal" i den forstand, at den opfylder sønnens begær efter at tage faderens plads, og Ødipus' begær og hans skæbne er sammenfaldende. Jesus, der repræsenterer begæret efter at erstatte faderen, bærer skylden for begæret gennem sin $\mathrm{d} \varnothing \mathrm{d}$, men bliver samtidig forvandlet til fader. I jødedommen er der ikke en sådan forsoningsdialektik (20).

Guden, der taler, "fordriver" (forskyder) så at sige subjektet. Ligesom Ødipus bliver fordrevet fra sin oprindelse i den græske tragedie, således bliver også det etiske - eller jødiske - subjekt fordrevet ved at blive "udvalgt" gennem det guddommelige ords imperativ. Forskellen mellem subjektet selv og den Anden består; den bryder ikke sammen i en erotisk drift efter at bringe den Anden tilbage til det samme. I jødisk tænkning er forskellen mellem faderen og sønnen uigenkaldelig. Der er ikke nogen "opfyldelse" af ordet i en ontologisk tilbagevenden til identiteten af fader og $\varsigma \varnothing \mathrm{n}$, som i kristendommen. Skriften, teksten som gave, er faderens nærvær-i-fravær. Gennem teksten bliver subjektet grebet og besat sønnen er besat af faderens stemme.

Forskellen mellem den græske skæbne (det tragiske) og det jødiske kerygma 
(det etiske) er da i Lyotards øjne forskellen mellem Ødipus og Hamlet: repræsentationen af begær, der opfylder sig selv i ikke-anerkendelsen (Ødipus), og begær, der ikke opfylder sig selv i tvangsmæssig repræsentation (Hamlet), hvor subjektet forskydes i forhold til sit begær (21). For Lyotard er forskellen mellem moderne og græsk tænkning præcis dette spørgsmål om opfyldelsen af det faderlige ord.

Her er det også interessant at bemærke, at en stor del af Derridas diskussion af Hegel i Glas centrerer sig omkring Hegels tidlige tekst Geist des Christentums, hvor Hegel diskuterer kristendommen som den hellige families religion par excellence. Ifølge Gayatri Spivaks læsning af Glas hævder Derrida, at det, jøderne ikke kan forstå, præcis er forholdet mellem de kristne og den guddommelige fader, specielt forholdets kombination af endeligt og uendeligt: "...hvad jøden ikke kan forstå...er kommensurabiliteten af overgangen mellem de to, tilstedeværelsen af det umådelige i det bestemte, af skønheden og immanensen i det endelige" (22). Spivak tilføjer, at jøden måske er "nægtet" enhver forståelse af den filosofiske dom som procedure. Derrida siger:

I alle domme er det den bindende og sammenklæbende placering af copolaet $\mathrm{er}$, der forener subjekt og prædikat, sammenfletter den ene med den anden for at danne ét eneste væsen... Denne forening, som forudsætter - déjà - en forsoning, der på en måde producerer den almene ontologiske sætning, er også en forsoning af det uendelige med sig selv, af Gud med sig selv, af mennesket med Gud som en enhed af fader-til-søn (23).

Jøden er uforsonet: han lever i begærets, forskellens og forskydningens område - ikke i opfyldelsens, identifikationens og enhedens område. Derfor er det ikke så underligt, at Derrida i sit essay om Jabès beskriver udvekslingen mellem jøden og den hellige skrift som en "langvarig metonymi". Metonymi i den lingvistiske betydning, som Roman Jacobson har givet det, betyder signifianternes nærhedsrelaterede serielle spil gennem kombination og kontekst. Metaforen er tegnets arrangement gennem erstatning og selektion (24).

\section{Hæretisk hermeneutik: identifikation og forskydning}

Vi kan nu bedre forstå den forskudte rabbinisme hos Derrida og den jødiske hæretiske hermeneutik. Vi kan tænke forskydningen på to måder: som en metonymisk omplacering efter nærhedsprincippet, eller en metaforisk form for annullering ved erstatning af et udtryk med et andet (billedligt i stedet for bogstaveligt). Og i denne betydning kan metonymi siges groft set at karakterisere rabbinsk tænkning, og metafor at karakterisere kristen tænkning. Det vil sige, at de centrale bevægelser i den kristne tænkning er erstatninger - af bogstav med ånd, af 
mennesket med den sonende (erstatnings-)ofring af Jesus, erstatningen af den mundtlige rabbinske Tora med Jesus selv osv. Fra et rabbinsk synspunkt er disse erstatninger fordrejede forskydninger, som blandt andet forvandler metonymi til metafor, en forskydning, der simulerer en erstatning, hvori den metonymiske distance mellem menneske og Gud, begær og opfyldelse, subjekt og prædikat, falder sammen. Disse forskydninger omskriver og $\emptyset$ delægger oprindelserne, underlægger sig faderen og bryder den metonymiske kæde.

Det afgørende punkt for den hæretiske hermeneutik er imidlertid, at den rabbinske tænkning i sig selv gennem sine egne forskydninger indeholder kimen til, muligheden for dette kætteri. Faktisk er selve den rabbinske forskydning fra naturen til den hellige skrift en nedbrydning af den biologiske successions- og nedstamningslogik. Det er trivielt at iagttage dette i temaet om den broderlige usurpation i Bibelen, bruddet på den naturlige afstamningslinje i historierne om Jakob og Esau, Isak og Ismael osv. Også rabbinerne frembringer, som vi har set, i deres rolle som samtalepartnere med Gud, skarpsindige forskydninger, som sætter dem i stand til at uddrage nye identiteter og kræfter af teksten. Den jødiske søn vil samtale med Gud, vil fors $\emptyset$ ge sine forskydninger gennem fortolkning; den kristne søn vil selv blive Gud, opløse spændingerne gennem en afskaffelse af den metonymiske diskurs.

Forskydning, usurpation, erstatning. Problemerne om frembringelse, succession "signifiantkæden", bevidsthedens forsinkelse og fortolkeren er alle centrale spørgsmål her. I sin forsinkelsespoetik postulerer Harold Bloom en "angst for påvirkning", i hvilken digtere kaster sig ud i en dialektisk-historisk kamp, hvor hver enkelt søger at skabe plads til sig selv ved at manipulere den tradition, som han er arvtager til, og hævde at han reviderer den og renser den for fejltagelser, mens han i virkeligheden i det skjulte kuldkaster sine forgængere. Gennem denne reviderende fortolkning kan digteren se sig selv som sin egen fader, frelst fra fejltagelser, og således gøre faderen til en foregribelse af sønnen. Blooms beskrivelse af den digteriske proces kan illustrere aspekter af den hæretiske jødiske hermeneutik, som jeg har søgt at formulere. Den hæretiske hermeneutik er et kompleks af identifikation og forskydning. Hvad enten Moses skal forstås som en foregribelse af Jesus, som i en kristen fortolkning, eller som en foregribelse af Freuds heroiske verdslige profeti, som i Freuds egen identifikation med den jødiske leder, så er dynamikken den samme. Den døde fader i Totem og tabu, Moses og monoteismen eller i Drømmetydning, eller fadernavnet hos Lacan, eller alle filosofiens fædre hos Derrida - alle tvinger de de levende sønner til at påtage sig en vis skyld, og til et begær efter at blive fri for denne byrde. Og friheden kommer på en karakteristisk rabbinsk måde - gennem fortolkning, men her en bevidst misfortolkning, eller "misprision" med Blooms ord. Under dække af en ny fortolkning bliver den metonymiske kædes rækkefølge brudt. 
Vi kunne sige, at en from rabbinsk fortolkning indebærer successionen af leddene i den metonymiske betydningskæde, en kæde, hvor signifie og signifiant ikke smelter sammen. Den ene kommer kun i forbindelse med den anden gennem en tilnærmelsesvis fortolkning, og identitet oprettes gennem en placering langs ad denne kæde inden for dens flertydighed. Hæretisk rabbinsk fortolkning er, ligesom for eksempel kristendommen, en fortolkning i form af et brud på de successive led og forskydning via metaforisk erstatning, en forening af signifiant og signifie, det samme og det andet, begær og opfyldelse, ordet der bliver til kød.

På den anden side er de rabbinske samtalepartneres forskydninger også en dialektisk identifikation med faderen. I Derridas tilfælde er den hæretiske hermeneutik, alt imens den er en forskudt rabbinisme, også samtidig en tilbagevenden til en identifikation med en form for jødisk paternitet, som så længe har stået i modsætning til og var undertrykt (og forskudt) af den græsk-kristne tradition... og det indser vi til en begyndelse i Derridas lidenskabelige forsvar for écriture.

\section{Lingvistikkens omstrejfende udskud}

Barbara Johnson stiller et vigtigt spørgsmål i sin klartfattende kritik af Derrida. Hvis det skulle tages alvorligt, siger hun, ville Derridas uendelige signifiant-spil kræve, at hans spil bevægede sig hinsides skriftens sem. Er resultatet ikke, at Derrida transformerer "skriften" til "det skrevne"? spørger hun (25). Derridas valg af skriften som modpol til vestlig logocentrisme er, påstår jeg, en genopdukken på forskudt måde af den rabbinske hermeneutik. Derrida vil nedbryde den græsk-kristne teologi og flytte os tilbage fra ontologien til grammatologien, fra væren til tekst, fra logos til écriture - hellig skrift.

Han vil forsvare skriften, der så fejlagtigt har været fordømt og foragtet, og bogstavet, der er blevet tugtet som en bærer af døden. Vi har behandlet dette stigma i den kristne polemik mod jøderne, men Derrida sporer det lige fra den græske filosofi til Rousseau, Saussure, Husserl og endda Levi-Strauss. Den faldne, bogstaveligt døde skrift modstilles en naturlig, levende, ærværdig metaforisk skrift - for eksempel. "samvittighedens stemme" som guddommelig lov eller hjertets tale osv. En sådan naturlig skrift er ikke grammatologisk, men pneumatologisk (26). Kontrasten mellem en sjælens eller kroppens, en indre eller ydre, en bevidsthedens eller lidenskabens skrift osv. befaler, at man må vende tilbage til "Naturens stemme", der smelter sammen med den guddommelige inskription.

Derrida påviser denne "onto-teologis" hårdnakkethed, selv hos verdslige tænkere. Skriften ses ikke blot som noget ydre, men som noget truende ydre, som det talte sprog må beskyttes imod, en ødelæggende trussel, der kan bryde ud og 
sprænge sjælens og den hellige families selvindesluttede indvendighed. I sin behandling af "lingvistik og grammatologi" i Om grammatologi hævder Derrida, at Saussure ser skriften som en "perversion og demoralisering, en forfalskningens og forklædningens dragt, en djævlemaske, som må bortmanes, det vil sige afværges, gennem det gode talte ord", ja endda som "arvesynden". Derrida er en vital polemiker, som er en mester i at forvrænge andres argumenter, så de passer til hans egne behov, men hans særlige brug af passager og adjektiver til at karakterisere negative holdninger til skriften er ret besynderlig: "den perverse kult omkring skriftsbilledet", "afgudsdyrkelsens synd", "perversion som avler uhyrer", "afvigelse fra naturen", "dødsprincippet", "misdannelse, helligbrøde, forbrydelse", "lingvistikkens omstrejfende udskud", "forvist, fordømt til omstrejfen og blindhed, til sorg", "den udstødte anden". Beskrivelserne er åbenlyst teologiske, og hvis der kommer en logos ud af "den historiske vold fra en tale, der drømmer sig fuldt ud nærværende for sig selv, lever sig selv som en tilbagetagelse af sig selv...det erklærede levende ords selv-produktion...en logos, som tror at være sin egen fader og således løfter sig op over den skrevne diskurs" (27), så er det tydeligvis den kristne logos, sønnen, der drømmer om at være sin egen fader, født ind i kødet og hævet over al tekst og skreven diskurs - og det forviste, omstrejfende, sørgende, fordømte udskud, beskyldt for en uforløst arvesynd, er jøden, bæreren af bogstavet, dyrkeren af skriften.

Det er underligt, at Derrida ikke nævner denne meget indlysende pointe, specielt da han er så ivrig efter at afdække de teologiske forudsætninger for denne logos' fortrinsstilling i essays, der er skrevet tidligere eller samtidig med $\mathrm{Om}$ grammatologi, og samlet i L'écriture et la différence. Derrida drager helt klart forbindelsen mellem den jødisk/kristne polemik og filosofiens historie. Vi har allerede nævnt essayet om Edmond Jabès. Derrida behandler det samme spørgsmål i et langt beundrende stykke, "Vold og metafysik", om den franskjødiske filosof Emmanuel Lévinas, der har haft stor indflydelse på ham, og i "Ellipse", der er det afsluttende essay i L'écriture et la différence, skrevet specielt til bogen. I det sidste stykke argumenterer Derrida for en "negativ ateologi", en skrift, der transcenderer "bogens" lukning til fordel for "tekstens" åbenhed. Han underskriver essayet "Reb Derissa". Dermed bliver hans underskrift de sidste ord i hele bogen. ÆEndringen fra Derrida til Derissa, fra "-ridda" til "-rissa" på fransk, kunne være et af de spil med ord og på sit navn, som Derrida er så glad for. Hvis vi går ud fra, at risée på fransk betyder "leende eller latterlig", så forsøger Derrida måske at være den, der ler sidst som "Reb" eller rabbi, Derrida som et elliptisk rabbinsk kommenterende tekst-spil.

Men før vi lader ham få den sidste latter, hvilket så mange af nutidens kritikere synes alt for villige til, så lad os tage ham lidt mere på ordet. Derrida ville selvfølgelig protestere, idet selve hans teori om fri-spillet, en del af hans arv fra 
Nietzsche, forlanger, at vi ikke tager ham på ordet, fordi der ikke er nogen "egentlig", enkelt, absolut "sand" mening, og derfor kan Derrida afværge ethvert teoretisk angreb og atter hævde sit herredømme over alle kritikere. Derridas dekonstruktive læsninger skrider sædvanligvis frem gennem en påvisning af, hvordan den behandlede forfatter begår de samme fejl, som han beskylder andre for. Derrida dekonstruerer dermed, eller ødelægger, forfatterens eget teoretiske grundlag. Jeg vil hævde, at der også hos Derrida er en uerkendt forskudt teologi, en forskudt rabbinisme, brugt både til at nedbryde den græsk-kristne kultur og til en negativ og dialektisk identifikation med en forskudt og undertrykt jødisk hermeneutik.

Så lad os opfatte Reb Derissa, den leende rabbi, mere i Midrash' ånd end i Nietzsches, betragte hans spil som et "alvorligt spil", som en kommentar, der er en udvidelse af teksten. Som Gayatri Spivak skriver: en af de betegnende karakteristika ved Derridas metode, som han har arvet fra Freud, er en fortolkende metode, som lægger mærke til de mindste detaljer ved en tekst, til syntaksen, til ordenes former - drømmens behandling af ord som ting (28). Dette er i sidste ende en art Midrashisk spil, som gør Derridas dekonstruktioner så forskellige fra Heideggers eller Nietzsches "destruktioner". Geoffrey Hartman skriver:

Derrida lader sproget være, ikke ved skødesløshed, men ved at give det dets "at være", idet han dekonstruerer en tekst eller bevæger sig inden for, snarere end blot imod, tvetydigheden og ordenes mangfoldige register. Tag ikke fejl af denne ikke-bog: Glas er af Galileis hus.

Hvem andre end Reb Derissa kunne gå fra dessemination/kastration eller blomst/sværd temaet og til Wartburg ordbogen [i Glas] (59 ff.), og ved en fejltagelse...så forvirret som nogen semantiker har opsporet, vise hvordan sværd og lilje ligger sammen (lilje/seng [lis/lit]) i 'glaïeuil' (gladiolus: svardlilje) med dens blomsterst $\phi v$ af foniske og dialektiske resonanser: glageuil ("klage", "deuil"?); glaudius, claudio, gaudio ("joy"?); glaviol ("viol"?); glaive, glai, englasi ("forfærde", "fryse", "glassere"?); glai, glace, glisser? (29).

\section{Athen og Jerusalem}

I et mere alvorligt øjeblik spørger den leende Reb Derissa i slutningen af essayet om Lévinas:

Er vi jøder? Er vi grækere? Vi lever i forskellen mellem jøden og grækeren, hvilket måske er enheden i det, der kaldes historie. Vi lever i og af forskel, det vil sige i hykleri...

Er vi grækere? Er vi jøder? Men hvem vi? Er vi (ikke et kronologisk, men et præ-logisk spørgsmål) først jøder eller først grækere? Og har den mærkelige dialog mellem jøden og grækeren, selve fredsslutningen, form af Hegels absolutte, 
spekulative logik, den levende logik, som forsoner formal tautologi og empirisk heterologi...? Eller omvendt, har denne fredsslutning form af en uendelig seperation og af den andens utænkelige, usigelige transcendens? Til hvilken fredsslutningshorisont hører det sprog, som formulerer dette spørgsmål? Hvorfra henter det energien til sin spørgen? Kan det gøre rede for den historiske kobling af jødedom og hellenisme? Og hvad er legitimiteten, hvad er meningen med copula'et $i$ denne sætning fra den måske mest hegelianske af moderne forfattere: "Jødiskgræsk er græskjødisk. Ekstremer mødes"? (30).

Filosofiens historie er i sidste instans en diskussion mellem jøder og grækere. Lévinas har i sine mange indflydelsesrige filosofiske værker taget den jødiske side op. Lévinas' indflydelse på Derrida nævnes ikke ofte. Derrida vedkender sig det åbent i essayet om Lévinas, som begynder med Matthew Arnolds berømte citat fra Culture and Anarchy om hebræismen og hellenismen som kulturens to vigtigste kræfter. Derrida påpeger, at filosofien er græsk i den mest etnocentriske betydning, og selv Husserl og Heidegger, der søger at underordne og overskride den metafysiske tradition, er ikke fri for græske elementer. "Her", skriver Derrida, "kan Lévinas' tænkning få os til at skælve. I hjertet af ørkenen, i den voksende фdemark, får denne tænkning, der ikke længere vil være en grundlæggende tænkning af væren og fænomenalitet, os til at drømme om en ufattelig demonterings- og afhændelsesproces". Hos Lévinas finder Derrida et fors $\emptyset \mathrm{g}$ på at "forstyrre den græske logos", og dermed forstyrre vores identitet og identitetsprincippet i almindelighed, hvilket er en opfordring til at lægge afstand til Grækenland, at frigøre tænkningen fra "undertrykkelsen" fra det Samme og det Ene, en "ontologisk eller transcendental undertrykkelse", som Derrida hævder er "oprindelsen til eller alibiet for al undertrykkelse i verden" (31).

Hos Lévinas ser vi et "fadermord på den græske fader Parmenides", som Derrida formulerer det. Temaet om mordet på den oprindelige fader og bemægtigelsen af oprindelserne træder her igen frem. Også Derridas dekonstruktionisme vil myrde filosofiens fædre-grundlæggere og udbrede en skrift, som i kølvandet på undergangen af det Samme og det Ene fejrer pluralismen, andetheden, distancen og forskellen. Parmenides' ignorering af det Andet er "totalitær" og tautologisk ifølge Lévinas og Derrida, og oprøret mod grækerne er en form for frigørelse.

I stedet for nærvær, eller ousia, vil Derrida sætte sin skrift, som er "mere 'metafysisk' end tale". Den skrivende kan bedre distancere sig, henvende sig mere effektivt til den anden, kan bedre udsætte, forsinke, formere tegnene og fornægte voldens umiddelbarhed. Og Lévinas lærer Derrida, at hebræisme med dens forbindelse til bogstavet har meget at lære os. Derrida citerer tre passager fra Lévinas: 
"At indrømme litteraturen en indvirken på menneskene det er måske Vestens højeste visdom, hvori Bibelens folk vil kunne genkendes".

"Ånden er fri i bogstavet, og undertvunget i roden".

"At elske Toraen mere end Gud [er] en beskyttelse mod galskaben ved en direkte kontakt med det hellige" (32).

Det sidstnævnte citat henter Derrida fra Lévinas' Difficile Liberté: essai sur le Judaisme, som er værd at unders $\emptyset$ ge nærmere for at spore de jødiske kilder til nogle af Derridas ideer. "At elske Toraen mere end Gud" er titlen på essayet, en titel, som stammer fra det berømte udsagn, fundet i Midrash og Talmud, og som rabbinerne lægger i Guds mund: "Således skulle det være, at du ville svigte mig, men ville overholde min Tora" (Yer. Hagigah 1:7, Lam. Ber. Rab., intro. kap. 2). Udsagnet er slående og eminent rabbinsk - Toraen, loven, den hellige skrift, siger Gud, er mere vigtig end ham selv. Vi kunne sige, at Derrida og den jødiske hæretiske hermeneutik gør præcis dette: svigter Gud, men foreviger en Tora, en hellig skrift eller lov på deres egen forskudte og ambivalente måde. Frem for alt forbliver Derrida trofast over for den stakkels eksilerede syndebuk, "skriften".

Man skal lægge mærke til, at Lévinas skriver en særegen post-Holocaust fransk-jødisk filosofi. Han er selv en overlevende fra lejrene, og erfaringen af Guds fravær er hovedanliggendet for hans essay om Toraen og Gud. Holocaust' ens fraværende Gud, guden, der skjuler sit ansigt, bliver for Lévinas på paradoksal måde betingelsen for den jødiske tro. Tabet ef en trøstende, barnlig himmel, det øjeblik Gud trak sig tilbage fra verden, er det øjeblik, der kræver, hvad Lévinas beskriver som en "voksentro", hvor den voksne kun kan triumfere i sin egen samvittighed og lidelse, en lidelse, som ikke er nogen "mystisk udsoning af verdens synder", men en prøvelse af et voksent ansvarligt menneske, "den retfærdiges lidelse for retfærdigheden uden triumf, [der] bliver levet som jødedom". Forholdet mellem mennesket og Gud i Jerusalem er

ikke et følelsesmæssigt fællesskab i kærlighed til en inkarneret Gud, men et forhold mellem ånder gennem en formidlende lære, Toraen. Det er præcis en diskurs, som ikke er legemliggjort i Gud, der sikrer os en levende Gud iblandt os... [At elske Toraen mere end Gud er en] beskyttelse mod galskaben ved direkte kontakt med det hellige uden fornuftens formidling.

...Det åndelige viser sig ikke som en holdbar substans, men snarere gennem sit fravær. Gud bliver virkeliggjort, ikke gennem inkarnation, men snarere gennem loven (33).

Jødedommen defineres da som denne tro på en fraværende Gud.

I sin kommentar til dette essay drager Richard Sugarman den vigtige pointe, at hos Lévinas betyder en fraværende retfærdighed ikke en ikke-eksisterende 
retfærdighed. Sugarman fortsætter:

Denne afgørende metafysiske skelnen mellem fænomenerne fravær og ikke-eksistens, der så længe er blevet fordunklet i filosofiens historie, er central for Lévinas' analyse og trænger til at blive yderligere ekspliciteret. Fravær er ikke det, som blot er et andet sted, og kan forvandles til nærvær ved at skifte position, perspektiv eller fortolkning. Det, som er fraværende, er ikke nødvendigvis en entitet, der befinder sig et andet sted, skjult for synet eller uforståeligt. Det er snarere sådan, at fraværsfænomenet præger vores forståelse af hverdagshændelser med en anselig konkret betydning (34).

Dette punkt er afgørende for forståelsen af skismaet mellem jøder og grækere og mellem Derrida og filosofiens historie: fravar er ikke det samme som ikkeeksistens. Fravær, andethed, "sporet", alle Derridas vigtigste begreber, er en del af et vokabular, som søger at undgå den fælde, der hedder Væren eller IkkeVæren i den græske filosofi. Derridas virkelighed er ikke Væren, men Fravær; ikke det Ene, men det Andet; ikke Enhed, men pluralitet, spredning, skrift og forskel. Også Reb Derissa hævder, at "det åndelige ikke viser sig som en holdbar substans, men snarere gennem sit fravær", og han er fraværs-religionens nye ypperstepræst.

Derrida er enig med Lévinas i, at hørelsen står højere end synet, for at se ansigtet er nærvær, ousia. Og det er i samtalen med Gud, den fraværende Anden, at Lévinas begrunder sin rabbinske metafysik. Derrida skriver i sin kommentar:

Det, at mennesket ligner Gud, tjener som en passage hvorigennem menneskets tale løftes op til Gud; denne næsten uhørte analogi er selve drivkraften i Lévinas' diskurs over diskursen. Analogi som dialog med Gud: "Diskurs er diskurs med Gud...Metafysik er selve essensen af denne samtale med Gud". Diskurs med Gud og ikke i Gud som participation. Diskurs med Gud og ikke diskurs om Gud og hans attributter som teologi. Og det usymmetriske i mit forhold til den anden, denne "krumning af det intersubjektive rum, betyder den guddommelige hensigt bag al sandhed". Den "er måske selve nærværet af Gud". Nærvær som adskillelse, nærvær-fravær - igen bruddet med Parmenides, Spinoza og Hegel, som kun "ideen om en skabelse ex nihilo" kan fuldbyrde. Nærvær som adskillelse, nærvær-fravær som lighed, men en lighed, der ikke er det "ontologiske mærke", som en arbejder præger i sit produkt, eller i "væsener, skabt i hans billede og i lighed med ham" (Malebranche); en lighed, som hverken kan forstås i fællesskabs- eller vidensbegreber, eller som participation eller inkarnation. En lighed, som hverken er et tegn på eller en virkning af Gud... "sporet af Gud" (35).

Derridas analyse af Lévinas er også en træffende sammenfatning af de tendenser 


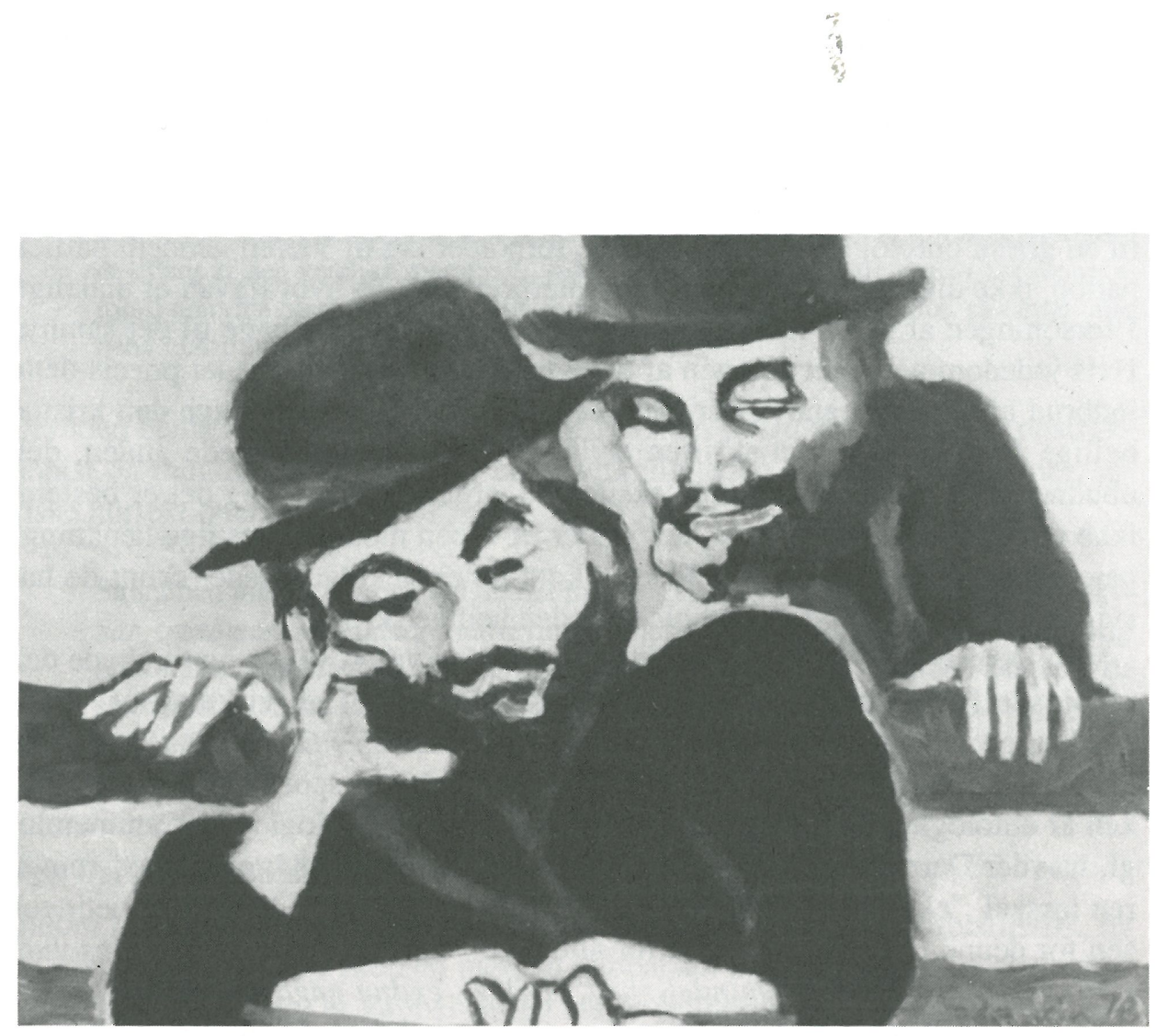

reading 
i den rabbinske tænkning, som vi har behandlet: en hermeneutik udviklet uafhængig af ontologien; en tekst hvis skrift præcis er dette nærvær-som-adskillelse, og som ikke er struktureret omkring en stor hierarkisk værens-kæde, men som tænker sig metafysikken som en diskurs med Gud, endeløs dialog og disput, fortolkning og genfortolkning. Kristendommen er på den anden side bundet til en græsk ontologi, hvor det værende forholder sig til Væren gennem participation, ikke diskurs; inkarnation, ikke interpretation; og hvor fravær er utåleligt. I forsoningen af logos med sig selv må det andet vende tilbage til det samme. Hvis jødedommen er erfaringen af dette uendelige andet, så er det præcis dette indbrud af det totalt andet, der truer den græske logos - og tillige den kristne hellige familie. Ligesom skriften er jøden historisk den tugtede anden, den ubudne gæst, syndebukken, den eksilerede, afgudsdyrkeren, og det er bestemt ikke nogen tilfældighed, at de, der griber til våben mod den vestlige tænknings paternalske logocentrisme, er jøder. Skønt de er sækulariserede, skønt de har svigtet den jødiske Gud, "overholder de den hellige skrift".

Men Derrida ville gå længere end Lévinas. Han vil omvende og forskyde den rabbinske hermeneutik. Hvad nu hvis verden ikke er en virkning af "Guds spor", men omvendt - hvis "Gud er virkning af sporet"? I Om grammatologi bekender Derrida sin gæld til Lévinas for relateringen af spor-begrebet til kritikken af ontologien (36). Ved at erstatte ontologi og semiologi med grammatologi, hævder Derrida, at "forskel" går forud for enhver lighed; og sporet, som er ren forskel, "eksisterer" ikke som et nærvær uden for en fylde, men er betingelsen for denne fylde og går forud for alle tegn: "Sporet er netop den absolutte oprindelse af mening $i$ almindelighed. Hvilket, endnu engang, betyder, at der $i k k e$ er en absolut oprindelse til mening $i$ almindelighed. Sporet er den differeren, som giver anledning til fremtræden og betydning" (Om grammatologi, dansk overs., s. 139). Derridas sprogbrug her er mildest talt en form for mystifikation, et fors $\varnothing \mathrm{g}$ på at transcendere et tankesystem, som han betvivler, ved at anvende hans egne redskaber i en slags via negativa. "Oprindelsen" er "sporet", et nærvær som "i sig selv bærer bogstavets og åndens problem, kroppens og sjælens, og alle de øvrige, hvis essentielle beslægtethed vi har påpeget" (s. 149). Hele metafysikkens historie, hævder Derrida, med alle dens dualismer og monismer, har stræbt efter at reducere sporet og underordne det under logos' fulde nærvær og dermed ydmyge skriften. Denne onto-teologi bestemte værens mening som nærvær, parousia, liv uden forskel, fra Platon til uendelighedsmetafysikken: "Man bør altså ikke tale om en "teologisk fordom", på færde her og der, når det drejer sig om logos' fylde: logos som sublimering af sporet er teologisk som så-dan" (s. 149).

Harold Bloom, der altid slår ned på en forfatters reviderende blindhed i forhold til sine forgængere, fanger her Derrida. Bloom påstår, at "sporet", 
"skriften", "forskellen" alle klart optræder i den jødiske mystiske tradition - i kabbalistisk fortolkning:

Derrida siger, at alle occidentale metoder til analyse, udlægning, læsning, fortolkning blev skabt "uden nogensinde at stille det radikale spørgsmål om skriften", men dette gælder ikke kabbalaen... Også kabbalaen tænker i baner, der ikke er tilladt af den vestlige metafysik, siden dens Gud på en gang er Ein-Sof og ayin, totalt nærvær og totalt fravær, og dens indre indeholder dens ydre, så længe alle dens virkninger bestemmer dens årsager (37).

Desuden bemærker Bloom, at på trods af Derridas positur som ærkedekonstruktionist og munter nihilist udfører han i virkeligheden rabbinske revisioner, jødiske korrektioner af vestlig filosofi:

Skønt han intetsteds siger det, er det måske sådan, at han erstatter logos med davhar og således korrigerer Platon med en hebræisk sidestilling af skriveakten og artikulationstegnet med selve ordet. Meget hos Derrida er i samme ånd som de store kabbalistiske fortolkere af Toraen, fortolkere som skaber barokke mytologier ud af de elementer i den hellige skrift, som fremtræder mindst homogene i teksten (38).

\section{Reb Derissa, kabbalist}

Bloom foretrækker at se Derrida, ikke som "rabbinsk", men som kabbalistisk, og vil drage en afgørende skelnen mellem kabbalaen og den normative ortodokse jødedom. For Bloom er kabbalaen en stærk fejllæsning af den ortodokse kanon, en model for digtning og kritik, fordi den energisk manipulerer, åbner, fejllæser og reviderer traditionen i overensstemmelse med dens egen katastrofiske vision. Han fortolker kabbalaen som en ekstrem respons på det jødiske eksil - en lidenskabelig åbning af den hellige tekst for tidens og historiens sorger. Bloom læser/fejllæser faktisk Gershom Scholems mesterlige studier af kabbalaen (39), for Scholem har hævdet, at kabbalaen er den ekstreme udvidelse af den rabbinske frihed over for teksten, som vi tidligere har behandlet - fors $\emptyset$ get på i åbenbaringen at inkludere hele den senere tradition og kommentar, der vil tilbyde sig som forklaring af dens mening.

Som vi har bemærket, kan en sådan fri revisionistisk læsning blive antitetisk, når den er drevet ud i ekstremet, eller er under pres fra historiske eller andre katastrofer. Et katastrofalt eksempel inden for jødedommen er Shabbatai Zevi's falske og kætterske, messianske bevægelse i det syttende århundrede. Scholem præsenterer imidlertid kabbalaen og dens skiftende fordrejede manifestationer som længe havde været holdt i vanære af det nittende århundredes tyske, ratio- 
nalistiske lærde - som selve det livgivende hjerte i jødedommen. Og Scholem og kabbalaen kan hjælpe os til at forstå Derridas særlige hæretiske hermeneutik.

Som David Biale viser i sit studie over Gershom Scholem, blev kabbala, gnosticisme og sabbatisme "et magtfuldt våben for Scholem i hans fors $\emptyset \mathrm{g}$ på at nedbryde jødedommens dogmatiske definitioner ved at vise, hvorledes censurerede "kætterier" i den jødiske historie var lige så legitime som den normative tradition. Det argument, at sabbatistisk, messiansk kætteri var en del af den jødiske historie, blev hjørnestenen i hans mod-historie" (40). Scholems kritikere så imidlertid i denne revision af jødisk historie en manifestation af Scholems eget antinomiske standpunkt. Et fors $\emptyset \mathrm{g}$ p̊̊ at camouflere hans egen subversion ved at omtolke traditionen selv som subversiv, og et projekt, der skulle gøre hans egen verdslige fortolkning af jødedommen til en del af den normative jødiske tradition.

Hvis vi ignorerer det fordømmende aspekt af disse kritikker og tager udsagnene som beskrivende snarere end foreskrivende, så mener jeg, at de er uhyre tankevækkende. Ved at forstå det "hæretiske" som en "normativ" del af jødisk historie bliver Scholems "antinomisme" her til en tilbagevenden til traditionen. Og vi kan sige, at Freuds, Derridas og Blooms "hæretiske" impulser ligeledes er en dialektisk tilbagevenden til den jødiske tradition. Scholems hæretiske hermeneutik resulterer ikke i et brud med traditionen, men i en vision af kætteriet som noget i bund og grund traditionelt; og han demonstrerer dette gennem en særlig form for fortolkende kommentar til den hellige skrift. Hvad kunne være mere traditionelt? Paradokset er tilbagekomsten til traditionen ad kætteriets vej. Og denne bevægelse er præcis det, Scholem lokaliserer som det centrale for den kabbala, som med hans ord skabte en "ortodoks gnosticisme" - et oxymoront begreb, som er et godt udtryk for dette paradoks.

Biale viser, at Scholems stilling over for sine forgængere er modelleret over det, Scholem anser for at være kabbalaens stilling over for den normative jødedoms hellige skrifttradition: kabbalaen var selv en "mod-historie" inden for jødedommen, som tilegnede sig den og transformerede den ved at integrere mytiske, gnostiske og mystiske begreber i hjertet af monoteismen, og som dermed var i stand til at genoplive den.

Som kabbalaens mod-historiker søger Scholem også gennem sin verdslige historiske metode at placere sig selv inden for den jødiske tradition og dermed transformere den ved at afsløre kætteriet i hjertet af denne tradition - idet han således udvikler en hæretisk hermeneutik, der hævder at genoplive, selv når den ophæver traditionen. Scholem undersøger det, der var blevet overladt til "kælderen" i den jødiske historie - den underjordiske, undertrykte, subversive, esoteriske tradition, som har udgjort en modstrøm i forhold til den officielle version af jødedommen, der er skabt af historikere og rabbinere. Men i denne kælder 
finder man hemmeligheden bag den jødiske overlevelse. Parallellerne til Freud, Derrida og Bloom er indlysende: også de spiller rollen som outsidere i forhold til deres respektive "traditioner" - videnskabelige, filosofiske, litterære. Også de beskæftiger sig med selvets, eksistensens, poesiens "kældre", for der at ops $\varnothing$ ge de undertrykte, skjulte bevægelser, som er "kætteri" i forhold til det "normative" syn på selvet, på Væren, på litteraturen. Også de finder irrationelle, dæmoniske, mytiske hemmeligheder i hjertet af fornuften, videnskaben, den humanistiske tradition. Ved at afdække disse hemmelige "anarkiske" kræfter, nedbryder de det, der er blevet den normative "ortodokse" anskuelse, og gør det ydre til det indre. "Kætterier" bliver til "tradition", og de opnår en prioritet og en autoritet over de traditioner, de var kætterske i forhold til. Derrida nedbryder selve den vestlige filosofis oprindelser; Freud afdækker de kætterske begær ved selvets oprindelser; og Bloom $\varnothing$ delægger den forfinede tradition fra Eliot et al. ved at afsløre den vilde $\emptyset$ dipale krigsførelse i poesiens hjerte. Alle disse handlinger er bemægtigelser af traditionens originale tekster, omvendinger af dem gennem fortolkningskunst og samtidig troskabserkæringer over for den "hemmelige" tradition, som derpå bliver den "virkelige" tradition; og disse mesterlige fortolkere bliver Moses-figurer, der bringer åbenbaringen ned til folket fra det flammende bjerg. Disse fortolkningsmæssige formidlinger - hvor verdslige de end er - bliver de eneste mulige "åbenbaringer".

\section{Mystiske spor}

I dette dunkle område "krydser fortolkningen grænsen", revisionisme bliver til kætteri og kætteri til tradition. Den hæretiske hermeneutik fortsætter derfor, selv når den forsøger at overvinde traditionen. Punktet, hvor revisionisme bliver til kætteri, er imidlertid uhåndgribeligt. Scholem finder nøglen i kabbalisternes intense koncentration om det guddommelige sprogs natur, i deres fors $\emptyset \mathrm{g}$ på at gennemtrænge den inderste mening med den guddommelige tekst. Bloom læser faktisk netop kabbalaen som en teori om retorikken og markerer klartfattende affiniteten mellem det kabbalistiske syn på sproget og det derridaske:

Jeg har lært, langsomt og modstræbende, at sprog i relation til poesien kan opfattes på to gyldige måder. Enten kan man tro på en magisk teori om sproget, som kabbalisterne, mange digtere og Walter Benjamin gjorde, eller man må overgive sig til en gennemgribende lingvistisk nihilisme, hvilket i sin mest raffinerede form er den nye mode, kaldet dekonstruktion. Men disse to måder forvandler sig til hinanden ved deres ydre grænser...Er der forskel mellem en sprogets $a b s o-$ lutte tilfældighed og det kabbalistiske, magiske absolutte, hvori sproget er totalt overdetermineret? (41). 
Derridas forestilling om sporet er mærkelig enslydende med Scholems beskrivelse af det kabbalistisk mystiske "Gudsnavn". Det relevante i Scholems analyse er den kabbalistiske opfattelse af, at den skrevne Toras guddommelige sprog allerede var formidlet - og at essensen af det guddommelige sprog var det mystiske "Gudsnavn", som var indkodet i teksten. Således tænkes den hellige skrifts egentlige skrift at være sammensat af forskellige kombinationer og omstillinger af dette mystiske Navn (42).

Scholem forstår dette Gudsnavn som noget, der er ækvivalent med selve Guds essens, og som en emanation og en skabende kraft, der transcenderer ethvert menneskeligt sprog, enhver grammatik eller forståelse. Mens det selv er "over eller hinsides" mening - "meningsløs", som Scholem udtrykker det - er dette mystiske navn ikke desto mindre den uudtømmelige kilde til al mening og åbner således for en uendelig fortolkning: "Dette absolutte ord er oprindeligt meddelt i sin grænseløse fylde, men - og dette er det afgørende - denne meddelelse er ubegribelig!" (43). Den bliver kun begribelig, hvis den formidles gennem traditionens fortolkning.

Scholem foretager en grundlæggende distinktion mellem dette mystiske "meningsløse" ord og ordene i den hellige skrift og i den tradition, der fortolker den; for hvem kan kende meningen med det totalt "meningsløse" ord? Den radikale konsekvens, som kabbalisterne ifølge Scholem tilslører, og som han selv påstår at afsløre, er, at der "ikke findes sådan noget som den skrevne Tora i betydningen umiddelbar åbenbaring af de guddommelige ord". I den følgende passage kunne man erstatte "den skrevne Tora" med "tekst" og "den mundtlige Tora" med "fortolkning", og det ville lyde helt derridask:

Den skrevne Tora er selv formidlet; der er således kun og allerede fortolkning, kun den mundtlige Tora. Denne mundtlige Tora bibeholder imidlertid karakter af det absolutte og er bærer af den uendelige fortolkningsproces. I modsætning til ideen om åbenbaring i form af en bestemt meddelelse, er den åbenbaring, som endnu ikke har nogen bestemt mening, det ved ordet, som giver en uendelig rigdom af mening. Idet det selv er uden mening, er det selve essensen af fortolkelighed. For den mystiske teologi er dette et afgørende kriterium på åbenbaring (44).

Og det ser tillige ud til at være det afgørende kriterium for Derrida - et "oprindeligt" meningsløst spor, som ikke desto mindre er kilden til et uendeligt fortolkningsspil.

En anden passage, i Zohar - et af de centrale kabbalistiske værker, som beskriver skabelsesprocessen - indeholder en beskrivelse af et mystisk fænomen, som har påfaldende lighed med Derridas spor: 
Da den yderst Mystiske ønskede at åbenbare sig selv, dannede han først et enkelt punkt, som blev forvandlet til en tanke, og i denne udfærdigede han utallige tegninger, og han indprægede utallige graveringer. Inden i den hellige og mystiske lampe graverede han desuden en mystisk og meget hellig tegning, som var et vidunderligt bygningsværk, der stammede fra tankens midte. Denne kaldes MI [hvem?] og var begyndelsen til bygningsværket, eksisterende og ikke-eksisterende, dybt begravet, ukendelig af navn (Zohar 1b).

Men er genindstiftelsen af sporet så ikke også teologisk? kunne man spørge Derrida. Er "sporet" ikke på en måde dialektisk relateret til alt det, det negerer? Helt klar over disse indvendinger fors øger Derrida i sin behandling af Jabès i essayet "Ellipse" i slutningen af L'écriture et la différence at advare mod en "tilbagevenden til bogen". Bogen må til sidst lukkes og teksten åbnes, for "hvis lukningen ikke er endemålet, så protesterer eller dekonstruerer vi forgæves", siger Derrida som et ekko af Paulus' "Hvis Kristus ikke er opstået, så er jeres tro forgæves". Genlyden af Paulus er yderst afslørende; det er en variation over den jødiske hæretiske hermeneutik. Denne gang er det imidlertid ikke noget så plat som en inkarneret gud, der vil fortrænge skriften, men noget mere subtilt og langt mere jødisk - en tekst, "en skrift hinsides bogen". Denne skrift "simulerer" inkludering i bogen ved gentagelse af bogen, men lader sig ikke indpakke af bogens omslag. Det er "oprindelsesskriften, skriften, der genopsporer oprindelsen, forfølger og indhenter tegn på dens forsvinden, den tabte oprindelsesskrift"(45). Det, der tager oprindelsens plads, er ikke fravær, men et spor, det vil sige en oprindelse, med hvilken intet er begyndt. Og således et nyt drab på Moses, fordrivelse af faderen og gentilegnelse af faderen og oprindelsen, en ny skrift. Men denne gang en skrift, der søger at sikre sig selv imod alle fremtidige forskydninger ved at udspekulere en mystificerende ikke-terminologi, der hele tiden unddrager sig definition.

\section{At spille i eksil}

Derridas særlige form for jødisk kætteri er ikke en metonymi, der er blevet til metafor, men en metonymi, der er gået amok, en metonymi, der erklærer sig uafhængig af alle grundlag og dog gør krav på at være oprindelsen og loven for alt. Différance betyder hos Derrida at være forskellig fra og at udsætte eller opsætte. Mens derimod Lévinas hævder, at på et tidspunkt må der komme en afsløring, en forløsning, hvor længe den end er udsat. Derrida vælger at forblive i eksilet, uendeligt at sætte forskelle og udsætte - at spille. Derrida vil spille i intervallet mellem bog og bog, lege med "centret", og de-centrere oprindelsen gennem skriften. Han vil definere centret som blot et hul. Idet vi skriver hullet, "kaster vi os ind i den rene overflades horisontalitet, som repræsenterer sig selv 
fra omvej til omvej". Derrida bliver den, der ler sidst ad de mange bejlere til den skriftens nye trone, som er hans. Ingen kan dræbe denne nye Moses. Hvor som helst kan han tage en anden omvej eller vælge at afvige /at differere/. Derridas simulering af bogen er tilmed en simulering af filosofien, simuleret alvor, simuleret spil.

Derrida er den fortabte $\varsigma \varnothing n$, men uden anger, nydende sin eskapade. Geoffrey Hartman bemærker dette tema i Derridas teori om "dissemination", spillet med

"det, som ikke vender tilbage til faderen"... Det er et ord, som kastes bort, en $\emptyset$ deland uden håb om tilbagevenden. "Imitationen af naturen" tager nu naturen bogstaveligt og sætter billedet af en kreativ selv-spredning i stedet for den (sammen-)"fattede" imitation af et guddommeligt mønster: logos' "legein" (46).

Denne logos kan ikke vende tilbage til faderen, og ingen tekst kan vende tilbage til sin forfatter. Også Derrida er således fri for enhver synd, som hans egne ødsle tekster måtte begå. Han er sikret imod alle angreb og bebrejdelser. Denne nye tilsidesættelse af faderen frigør ham fra den arvesynd, som Freud så grusomt var bundet til i sin egen teori om fadermordet. Derrida vil lystigt udføre sin "kruci-fiktion af ordet", som Hartman siger det, uden anger. Han vil forblive i eksil og eksilere logos sammen med sig. Han vil ikke vende hjem, og han vil ikke byde Messias velkommen.

Hvis psykoanalysen kan ses som ét fors $\emptyset \mathrm{g}$ på at kurere neurosen hos jøden-ieksil, så kan dekonstruktivismen betragtes som et andet. Kafka gav følgende kommentar til psykoanalysens eksilkarakter:

Det er ikke nogen fornøjelse at beskæftige sig med psykoanalyse, og jeg holder mig så langt væk fra den som muligt, men den har i det mindste samme realitet som den nuværende generation. Jøderne har altid udviklet deres sorger og glæder næsten samtidig med at Rashi-kommentaren forholdt sig til dem, og det har de igen gjort her (47).

Marthe Roberts anfører til denne bemærkning, at Kafka finder meningen med Freud ud fra samtidens glæder og sorger i det jødiske liv, som er unikt derved, at det $\mathrm{i}$ umindelige tider "har været nødt til at tilvejebringe sin egen kommentar, det har altid været et skrevet liv, ikke frembragt før, men næsten samtidig med skrifterne, der forklarer det" (48).

Lad da kommentaren, den skrift der udvikles i eksilets endeløse forsinkelse, være alt, siger Derrida, og lad den være munter. Lad eksilet omstyrte væren og logos fuldstændigt. "Møde er adskillelse", skriver Derrida som et ekko af Lévinas, en sætning som "bryder værens enhed...ved at byde det andet og differensen velkommen i meningens udspring" (49). Dette 
oprindelige eksil fra værens kongerige betyder eksilet som begrebsliggørelsen af væren og betyder, at væren aldrig er, aldrig selv viser sig, aldrig er narvarende, aldrig er $n u$, uden for differensen... Hvad enten han er væren eller værens hersker, så er Gud selv, og fremtræder som det han er, i differensen, det vil sige som differens og i tilsløring [s. 74].

Det er denne differens i Gud, Derrida i essayet om Jabès refererer til som lovens knuste tavler, der tillader poetisk autonomi og den menneskelige tales frihed:

Mellem de ituslåede tavlers fragmenter gror digtet, og retten til at tale slår rod. Igen begynder tekstens eventyr som ukrudt, som fredløs langt fra "jødernes faedreland", som er en "hellig tekst omgivet af kommentarer" [s. 67].

Både digteren og jøden må skrive og må kommentere, fordi både digt og kommentar er former for eksileret tale, men digteren behøver ikke at være trofast mod eller bundet til en oprindelig tekst. For Jabès bliver loven, efter knusningen af tavlerne, til et spørgsmål, og at spørge bliver en pligt. De ituslåede tavler repræsenterer en negativitet og en differens i Gud, en skjulen og tilsløring af hans ansigt, som Derrida hævder er oprindelsen til vor frihed - og vores skrift. Derrida er her tiltrukket af det samme tema, som vi fandt hos Lévinas - den jødiske opfattelse af Guds fravær som hans nærvær, og Guds dobbelthed, hans skjulthed og indirekthed. (Og han erkender, at temaerne om "spørgsmålet i Gud... [om] negativiteten i Gud, eksil som skrift og bogstavets liv alle allerede findes i kabbalaen" [s. 74]. Kabbalaen taler for eksempel om Guds selv-sammentrækning, eller tzimtzum, som skabelsens grundlæggende bevægelse). Mennesket låner Guds omveje; denne uendelige omvej, eller "Guds vej", er "ikke underordnet nogen sandhed, og da den således mangler sandhedens strenge forskrift, er den vejen gennem ørkenen. Skriften er ørkenens moment i egenskab af adskillelsens moment" (s. 68).

Også Derrida slår sig ned her og rejser sit telt. Mellem fragmenterne af de tavler, han har ødelagt, gror hans tekster som "ukrudt", som "fredløse", der imiterer en skjult Guds kunstgreb, fravær og uendelige omveje. Derrida ønsker at florere i de spredte mellemrum mellem tavlerne, mellem jøde og græker, rabbiner og digter. Fravær, hævder Derrida, er "bogstavets æter og åndedræt"; betydning opstår gennem fravær, brud, fragmentering, gennem bogstavets diskontinuitet:

Det er cæsuren, der frembringer meningen. Den gør det selvfølgelig ikke alene; men uden afbrydelse - mellem bogstaver, ord, sætninger, bøger - kan der ikke vækkes nogen betydning. Hvis man går ud fra, at naturen afviser springet, kan man forstå hvorfor den hellige skrift aldrig vil blive natur. Den skrider kun frem gennem spring. Hvilket gør den farlig. Døden strejfer om mellem bogstaverne. 
At skrive det, der kaldes skrift, forudsætter en adgang til ånden gennem modet til at miste livet og dø bort fra naturen (s. 71).

For Derrida er fravær bogstavets grund og indhold. Dette bogstavets omstrejfende liv udtrykker sig frem for alt i metaforen, metaforen som sprogets oprindelse, hinsides væren og intet: "Metaforen eller det dyriske ved bogstavet er den primære og uendelige tvetydighed ved signifianten som liv. Den psykiske undergravning af den træge bogstavelighed, det vil sige af naturen, eller af talen, som er vendt tilbage til naturen" (s. 73). Dette er en brug af metafor, som ikke vender tilbage til en "naturlig" eller "rigtig" entydig mening, men som undergraver naturen. Sådan et metaforisk bogstav eller ord kunne aldrig blive inkarneret i kødet og vil ikke "returnere talen til naturen", som den kristne logos gør. Derrida vil stadig strejfe om blandt bogstavernes uendelige spil i den hellige skrift, mellem linjerne. Han er mere hjemme i den hellige skrift end i naturen, ligesom rabbinerne.

Men som vi har set, kan Derrida ikke forlige sig med at blive inden for bogens rammer. Han ville stille et sidste spørgsmål til Jabès' Spфrgsmålenes bog, et spørgsmål, som endelig ville frigøre Derrida fra bogens epoke og ophæve bogen som model for meningen. Han vil i stedet spørge, om ikke værens mening er en "radikal ulæselighed" (s. 77). Denne radikale ulæselighed, som karakteriserer en anden æra end bogens, er ikke "irrationel", hævder Derrida, den er ikke noget, der kan defineres i relation til logikken eller bogen. Den er snarere og først og fremmest en "oprindelig ulæselighed", som er selve bogens mulighed. "Den væren, der melder sig i ulæseligheden, er hinsides disse kategorier, hinsides sit eget navn, idet den skriver sig selv" (s. 77). (Igen ligner dette i slående grad kabbalismens uforståelige, mystiske guddommelige navn eller "punkt" forud for skabelsen).

Igen er det lysten til at forskyde oprindelserne, den jødiske hæretiske hermeneutik, der træder frem hos Derrida, som anbringer en radikal uforståelighed ved udspringet af sin tanke, en radikal ulæselighed, som faktisk konstituerer hans eget værk. Også han fors $\emptyset$ ger at skrive hinsides endeligheden i hans eget "egennavn" med hans fantasi om et dissemineret navn, som han placerer ved oprindelsen. Ligesom Freud har han sin egen form for familieroman inden for filosofiens familie, hvor han kan undergrave sine jødisk-græske oprindelser og afværge ethvert forsøg på at fange ham ved at slå sig ned i mellemrummet mellem linjerne. Derrida vil altid vælge at, men han efterlader sig ingen tomme pladser til nogen, der ville afvige/differe/ fra ham.

Han har både ophævet filosofiens historie og endda tilegnet sig de ubrugte, de meningsløse og selv de ulæselige steder. Selv her vil han imidlertid forstille sig for at sprede sig selv. De yderste spørgsål han stiller til bogen, må hvile, siger 
han. "Skriften ville dø af spørgsmålets rene årvågenhed, ligesom den ville af den simple udradering af spørgsmålet. Er det at skrive ikke endnu engang at sammenblande ontologi og grammatologi?" (s. 78). Derrida har alt for meget at tabe, hvis skriften skulle dø. Han må udsætte sine egne spørgsmål, ellers ville hans radikale angreb på oprindelsen og på bogen føre til hans egen opløsning og tavshed. Derrida må på en eller anden måde bestandiggøre loven, i det mindste være skriftens fader, for at undgå at fadermordet skal blive et upåagtet selvmord.

De jødiske fortabte sønner kan ikke helt give afkald på den hellige skrift. At angribe den europæiske psyke og den hellige logos, at forsøge på at omvælte det vestlige menneske indefra og udefra er en hævnakt fra de eksileredes side og samtidig et forsvar for den jødiske fader. Ikke desto mindre vil de fors $\emptyset$ ge at tilbageerobre det "stjålne bogstav", at frelse den hellige skrift fra den misbrug, den har været udsat for i hænderne på grækere og kristne. Og de vil frem for alt opnå deres sejr gennem fortolkningsakter.

For dem er der imidlertid ingen ende på eksilet. Der findes ingen opfyldelse af tegnene, men snarere en ophøjelse af eksilets jødiske vilkår til et paradigme på eksistensen: at være er at være i eksil; at fremstille tekster er allerede at fortolke; fravær er nærvær. Eller måske i reaktion på en hellig skrift, der i det uendelige lover uden at opfylde, vil de gøre deres eksil til et antitetisk forjættet land, en "kritik i vildmarken", for at anvende titlen på en af Geoffrey Hartmans seneste bøger.

Hvordan skal vi sluttelig forstå denne komplicerede sammenvævning af tradition, revision og kætteri? Kun lignelsens sprog kan i sidste instans indfange den. Kafka, der så smertefuldt delte denne påvirkningsangst og disse verdsligt-religi$\emptyset$ se dilemmaer, fortæller historien i en lignelse:

Leoparder bryder ind i templet og tømmer offerbægeret; dette sker gentagne gange, igen og igen: til sidst kan man kalkulere med det på forhånd, og det bliver en del af ceremonien (50).

Kafkas lignelse forekommer mig at være uhyggelig præcis i sin beskrivelse af Freud, Derrida, Bloom og den jødiske hæretiske hermeneutik. Det jødiske tempel var faktisk udsat for indbrud adskillige gange, og to gange blev det $\emptyset$ delagt; dets tilhængere blev sendt i eksil, fordrevet med en evig længsel efter at vende tilbage. I eksilets lange mellemspil erstattede studier og fortolkning af templets love og ritualer de egentlige ofringer. I eksilet søger et knækket folk at hele sig selv gennem en mere og mere kompliceret figurering, åbning og metaforisering af deres hellige tekst, søger på en eller anden måde at få deres historiske kata- 
strofes realiteter til at stemme med de eksalterede løfter i deres hellige bog. Og dette kan kun opnås gennem kunststykker af spidsfindig fortolkende omvending: hvordan det end er sket, er leoparderne kommet ind i templet og må indpasses uden at få lov at triumfere. Overdreven metaforisering, overskridende fortolkning, kabbalistisk omvending fremstår alle under dække af en udvidelse og anvendelse af den hellige bog, som en del af den udlæggende fortolkning af den. Præcis af denne grund er Bloom så tiltrukket af kabbalaen som et paradigme for al revisionistisk tænkning og som model for intrapoetiske kampe; han erkender den rabbinske fortolknings overdrivelser som overlevelsesstrategier, som "nødvendig fejllæsning", ikke bare i forhold til en historisk katastrofe, men også imod en overvældende autoritær, paternalsk hellig tekst, som aldrig kan overvindes.

Leoparderne, de oprørske, profanerende, kætterske kræfter er blevet en del af selve det hellige ritual - gennem fortolkning. "Forskydning" beskriver ikke blot en sådan ekstrem fejllæsning, er ikke blot en fortolkningsteknik: det er den eneste måde at overleve de endeløse forskydninger i den jødiske historie. Forskydning er en nødvendig re-vision og gen-skabelse af en tekst, som er det eneste anker for et folk, som er forskudt i rummet. Forskydning er med andre ord både eksilets vilkår og svar. Leoparderne bliver en del af ritualet. I den hæretiske hermeneutiks skole sammenblandes det hellige og det profane; der er noget helligt over skrift, kommentar og tekster, dog forskydes disse begreber ind i litteraturens, filosofiens og psykoanalysens profane felter. Samtidig profaneres templet og den hellige skrift under dække af reviderende fortolkning. Grænserne krydses: hvem ved i dag, hvad der er helligt, og hvad der er profant - hvem der er leoparderne, og hvem der er præsterne? 


\section{Noter}

1) Jacques Derrida, Glas (Paris: Galilée, 1974), s. 2686-69b, citeret og oversat i Gayatri Spivak, "Glas-Piece: A Compte rendu", Diacritics 7 (1977): 23. "Derrière les rideaux" har i sig indkodet stavelserne i Derridas navn: derri-da. Glas er fyldt med den slags selvindskrivende ordspil.

2) Spivak, "Glas-Piece", s. 23.

3) Jacques Derrida, "Edmond Jabès and the Question of the Book", i Writing and Difference, oversat af Alan Bass (1967; Chicago: University of Chicago Press, 1978), s. 64-67.

4) Ibid., s. 65.

5) Bloom fokuserer på dette centrale spørgsmål i alle sine seneste teoretiske værker: The Anxiety of Influence (New York: Oxford University Press, 1973); A Map of Misreading (New York: Oxford University Press, 1975); Kabbalab and Criticism (New York: Seabury Press, 1975); Poetry and Repression (New Haven: Yale University Press, 1976).

6) Simon Rawidowicz, "On Interpretation", i Studies in Jewish Thought, red. Nahum Glatzer (Philadelphia : Jewish Publication Society, 1974), s. 45-80. Se også "Israel's Two Beginnings: The First and the Second 'Houses'" i det samme bind, s. 81-209.

7) Geoffrey Hartman, Criticism in the Wilderness: The Study of Literature Today (New Haven: Yale University Press, 1980), s. 202.

8) Ibid., s. 206.

9) Rawidowicz, "On Interpretation", s. 52.

10) Jacques Derrida, Om grammatologi, oversat af Lars Bonnevie og Per Aage Brandt (1967; København: Arena, 1970), s. 56.

11) Ibid., s. 58.

12) Om dette emne generelt, se studierne af Thorlieff Boman, Hebrew Thought Compared with Greek (Philadelphia: Westminster Press, 1954); Isaac Rabinowitz,"'Word' and Literature in Ancient Israel", New Literary History 4 (1972): 119-130; og den eksistentialistisk filosofiske analyse af Lev Shestov, Athens and Jerusalem, overs.: Bernard Martin (Athens: Ohio University Press, 1966). Se også den udmærkede studie af G. Douglas Atkins, "Dehellenizing Literary Criticism^, College English 41 (1980): 76979 , som skitserer de anti-hellenistiske og pro-hebraiske tendenser i den litterære kritiks "Yale Skole" - Geoffrey Hartman, Jacques Derrida, Harold Bloom, Paul de Man, og J. Hillis Miller.

13) Hans Jonas, Philosophical Essays: From Ancient Creed to Technological Man (Englewood, N.J.: Prentice-Hall, 1973), s. 29.

14) Om dette emne, se Louis Jacobs, Studies in Talmudic Logic and Methodology (London: Vallentine, Mitchell, 1961); Tzvetan Todorov, "On Linguistic Symbolism", New Literary History 6 (1974): 11-34; Jacques Derrida, "The Supplement of Copula: Philosophy before Linguistics", i Textual Strategies: Perspectives in Post-Structuralist Criticism, red. Josué V. Harari (Ithaca: Cornell University Press, 1979), s. 82-120; og Susan Handelman, "Greek Philosophy and the Overcoming of the Word", Works and 
Days 1 (1980): 45-69.

15) Se Derridas lange essay om dette emne, "White Mythology: Metaphor in the Text of Philosophy", New Literary History 6 (1974): 5-74.

16) Paul Riceur, The Rule of Metaphor, oversat af Robert Czerny (Toronto: University of Toronto Press, 1977), s. 20-22.

17) John Freccero, "The Fig Tree and the Laurel: Petrarch's Poetics", Diacritics 5 (1975): 37.

18) Til en udvidet derridask læsning af Augustin, se Margaret Ferguson, "St. Augustine's Region of Unlikeness: The Crossing of Exile and Language", Georgia Review 29 (1975): 842-64.

19) Citeret hos Robert L. Wilken, Judaism and the Early Christian Mind (New Haven: Yale University Pres, 1971), s. 1.

20) Jean-François Lyotard, "Jewish CEdipus", Genre 10 (1977): 401-3.

21) Lyotard, s. 406. Han skriver også: "Hvad er der hos Hamlet, som ikke er hos Edipus? Der er ikke-opfyldelse. Dette kan opfattes som den psykiske dimension i neurosen eller den tragiske dimension i tænkningen. Det har en helt anden dimension. EEdipus opfylder sin skæbne af begær. Hamlets skæbne er begærets ikke-opfyldelse. Denne kiasme er den, der findes imellem det Græske og det Jødiske, imellem det tragiske og det etiske... I hebraisk etik er repræsentationen forbudt, øjet lukkes, øret åbnes for at høre Faderens talte ord. Billedet er forkastet på grund af dets opfyldelse af begær og bedrag. Dets sandhedsfunktion er fornægtet" (s. 400-402).

22) Derrida, Glas 99a, oversat af Spivak i "Glas-Piece", s. 33.

23) Derrida, Glas 67a, i Spivak, "Glas-Piece'", s. 33.

24) Roman Jakobson, "Two Aspects of Language: Metaphor and Metonymy", i European Literary Theory and Practice, red. Vernon Gras (New York: Delta, 1973), s. 121.

25) Barbara Johnson, "The Frame of Reference: Poe, Lacan, Derrida", Yale French Studies 55-56 (1977): 483.

26) Derrida, Of Grammatology, s. 17.

27) Ibid., s. 35, 38-39, 44.

28) Spivak, Introduction to Of Grammatology, s. xlv.

29) Geoffrey Hartman, "Monsieur Texte", i Saving the Text: Literature/ Derrida/Philosophy (Baltimore: Johns Hopkins University Press, 1981), s. 19.

30) Jacques Derrida, "Violence and Metaphysics: An Essay on the Thought of Emmanuel Lévinas", i Writing and Difference, s. 153.

31) Derrida, "Violence and Metaphysics", s. 82, 83. Se også Lev Shestov, Athens and Jerusalem, n. 12 ovenfor, en lang meditation over dette emne. En russisk jøde, der underviste i filosofi i Paris, Shestov, er formodentlig en af Derridas ubemærkede forløbere.

32) Derrida, "Violence and Metaphysics", s. 89, 102.

33) Emmanuel Lévinas, "To Love the Torah more than God", oversat og genoptrykt af Helen A. Stephenson and Richard Sugarman, Judaism 28 (1979): 218, 219. "Difficile liberté: essai sur le Judaism", i Presences du Judaism (Paris: Albin Michel, 1963), s. 218, 219. 
34) Sugarman, "Torah", s. 221.

35) Derrida, "Violence and Metaphysics", s. 108.

36) Derrida, Om grammatologi, s. 148. De følgende henvisninger til Om grammatologi er sat i parantes.

37) Bloom, Kabbalah and Criticism, s. 53.

38) Bloom, A Map of Misreading, s. 43.

39) Nogle af Scholems større arbejder er: Major Trends in Jewish Mysticism (1941; genoptryk New York: Schocken, 1961); On the Kabbalah and its Symbolism (1960; genoptryk New York: Schocken, 1969); Kabbalah (New York: New American Library, 1974); The Messianic Idea in Judaism and Other Essays on Jewish Spirituality (New York: Schocken, 1971); Shabbatai Zevi: The Mystical Messiah, 1626-1676, oversat af R.J.Z. Werblowsky (Princeton: Princeton University Press, 1973).

40) David Biale, Gershom Scholem: Kabbalah and Counter-History (Cambridge: Harvard University Press, 1979), s. 155.

41) Bloom, "The Breaking of Form", Deconstruction and Criticism, red. Bloom m.fl. (New York: Seabury Press, 1979), s. 4.

42) Se, for eksempel, Scholem, Major Trends; "The Meaning of the Torah in Jewish Mysticism", i On the Kabbalah, s. 32-86; "The Name of God in the Linguistic Theory of the Kabbalah", Diogenes 79 (1972): 59-80; og bd. 80 (1972): 164-94; og Biales diskussion i Gershom Scholem, s. 79-122.

43) Gershom Scholem, "Revelation and Tradition as Religious Categories in Judaism", i The Messianic Idea in Judaism, s. 294.

44) Ibid., s. 295.

45) Derrida, "Ellipsis", Writing and Difference, s. 294, 295.

46) Geoffrey Hartman, "Epiphony in Echoland", i Saving the Text, s. 48.

47) Brev til Franz Werfel, formodentlig ikke afsendt. Jf. brevene til Max Brod og Franz Werfel, december 1922 i Briefe 1902-24, red. Max Brod (New York: Schocken, 1958), s. 432 ff., citeret hos Marthe Robert, From CEdipus to Moses: Freud's Jewish Identity, overs.: Ralph Mannheim (New York: Doubleday-Anchor, 1976), s. 173, n. 12.

48) Robert, CEdipus to Moses, s. 8.

49) Derrida, "Edmond Jabès", Writing and Difference, s. 74. De følgende henvisninger til dette essay er sat i parantes.

50) Franz Kafka, citeret hos Hartman, Criticism in the Wilderness, s. 55. 